\title{
THE IMPORTANCE OF DESIGN IN BUSINESS PRACTICES OF CZECH COMPANIES
}

\author{
Jan Kramoliš, Pavla Staňková, Michal Richtr
}

\section{Introduction}

As a result of rapid changes and a growing competitiveness of companies at present, design is becoming one of the key instruments of innovation and also the key instrument of companies' performance [8], [1]. For the reason of having products more and more technically alike, it is the design that is becoming an instrument of competitiveness as well as the criterion for decision making of final consumers.

Innovation by Urabe, Child \& Kagono [19] consists of the generation of a new idea and its implementation into a new product, process, or service, leading to a creation of pure profit for the innovative business enterprise.

Design management is a term for which there is no clear-cut definition. However, it is evident that this term stands for connecting two fields - design and management.

Design by Bruce \& Bessant [3] is essentially the application of human creativity to a purpose - to create products, services, buildings, organizations and environments which meet people's needs. It is the systematic transformation of ideas into reality.

In the context of innovations, we are able to specify three interpretations of the term design [18]:

- Design is a tangible outcome.

- Design is a creative activity.

- Design is the process by which information is transformed into a tangible outcome.

Fairhead [18] refers to four different levels of understanding of design:

- Design is seen as "styling".

- Design is about better products.

- Design shares the interface between company and audiences.

- Design is integration: A whole process.

The connection of terms design and corporate is used by Vysekalová \& Mikeš [21].
In her point of view, the corporate design is a part of visual identity and it is a set of visual constants that is used in internal and mainly external communication. It includes following factors: name of the company and the way of its presentation, company logo, product brands, promotional items and printed materials, script and colour, structure and nomenclature of the buildings and interiors, employees wear, container graphics, gift items, etc. The graphical image of these components should be included in a so-called design manual. Design manual is a summary of rules and recommendations for printed and electronic visual presentations of the company, e.g. graphical rules, layout of the documents, rules concerning usage of founts, colours, logo and its variations, company documents, and the like.

By the Kathryn Best [5], in the area of design management a wide variety of perspectives exist that reflect the rich array of individuals, professions and context involved. Hollins [10] define design management as the organisation of the processes for developing new products and services.

Bruce \& Bessant [3] identify fundamental issues of design management:

a) How do particular perspectives fit into the design process and what they can bring?

b) How can design professionals support these different contributions?

c) How tolls/techniques are available to help make this contribution?

d) How can effectiveness of the design process be measured?

e) How can the process be improved?

According to Design Management Institute in Boston [6] definition encompasses Design management the ongoing processes, business decisions, and strategies that enable innovation and create effectively-designed products, 
services, communications, environments, and brands that enhance our quality of life and provide organizational success. On a deeper level, design management seeks to link design, innovation, technology, management and customers to provide competitive advantage across the triple bottom line: economic, social/ cultural, and environmental factors. It is the art and science of empowering design to enhance collaboration and synergy between "design" and "business" to improve design effectiveness. The scope of design management ranges from the tactical management of corporate design functions and design agencies, including design operations, staff, methods and processes-to the strategic advocacy of design across the organization as a key differentiator and driver of organizational success. It includes the use of design thinking-or using design processes to solve general business problems.

There is a strong link between marketing and design management which mentioned Gorb [7] and also Melewar, Dennis, Kent [13], and Adir \& Pascu [2] presents in their paper the importance of a logo as a graphic element to support a corporate identity. They described the basic idea: That the logo design is a creative work which allows to a company to be seen through a symbol as a visual and graphic message.

Design offers four powers or directions through which to create value in management, and these four directions can be seen as a system with the vision in the center according to Mozota [14], [15], [16]. The design value model and its application through the Balanced Score Card toolkit provide a common language for designers and managers and this can help the design profession effect a change from project-based to knowledge-based.

\section{Theoretical Background}

Walker [22] deals with a specific field of management. He presents the differences between managers and designers - see Tab. 1 . The differences between the managers and designers are mainly in the area of personality specialities, habits of thinking and working, and education background.

\section{Tab. 1: Differences between managers and designers}

\begin{tabular}{c|l|l} 
Characteristic & \multicolumn{1}{|c}{ Managers } & \multicolumn{1}{c}{ Designers } \\
\hline Aims & $\begin{array}{l}\text { Long term } \\
\text { Profits/return } \\
\text { Survival Growth } \\
\text { Organizational durability }\end{array}$ & $\begin{array}{l}\text { Short term } \\
\text { Product/service quality } \\
\text { Reform } \\
\text { Prestige } \\
\text { Career building }\end{array}$ \\
\hline Focus & People Systems & $\begin{array}{l}\text { Things } \\
\text { Environment }\end{array}$ \\
\hline \multirow{2}{*}{ Education } & $\begin{array}{l}\text { Accountancy } \\
\text { Engineering } \\
\text { Verbal Numerical }\end{array}$ & $\begin{array}{l}\text { Grafts Art Visual } \\
\text { Geometric }\end{array}$ \\
\hline \multirow{2}{*}{ Thinking style } & $\begin{array}{l}\text { Serialist Linear } \\
\text { Analysis } \\
\text { Problem oriented }\end{array}$ & $\begin{array}{l}\text { Holist Lateral } \\
\text { Synthesis } \\
\text { Solution led }\end{array}$ \\
\hline Behaviour & $\begin{array}{l}\text { Pessimistic } \\
\text { Adaptive }\end{array}$ & $\begin{array}{l}\text { Optimistic } \\
\text { Innovative }\end{array}$ \\
\hline Culture & $\begin{array}{l}\text { Conformity } \\
\text { Cautious }\end{array}$ & $\begin{array}{l}\text { Diversity } \\
\text { Experimental }\end{array}$ \\
\hline
\end{tabular}


Design management according to Kathryn Best [5] includes three main phases:

1. Managing design strategy - the aim is the identification and looking for conditions most suitable for having successful design management. This includes mainly implementation of design into organization strategy, identification of opportunities for design, interpretation of will and needs of the customers, and looking for benefits of design for business;

2. Managing design process - it is the realization of design itself and making it visible. It helps the organization identify opportunities for particular projects concentrating on design, making a creative team, visual communication of the organization and presenting its ideas outward;
3. Managing design implementation this phase concentrates on particular project management in practice, design specification, specifying the level of cooperation and ethical responsibility. The evaluation of the project forms an essential part of the implementation that provokes positive response regarding design efficiency.

Verganti [20] introduces the term designdriven innovation. He also defines three phases related to innovation management by means of design:

a) listening,

b) interpreting,

c) addressing (see Fig. 1).

\section{Fig. 1: Phases related to innovation management by means of design}

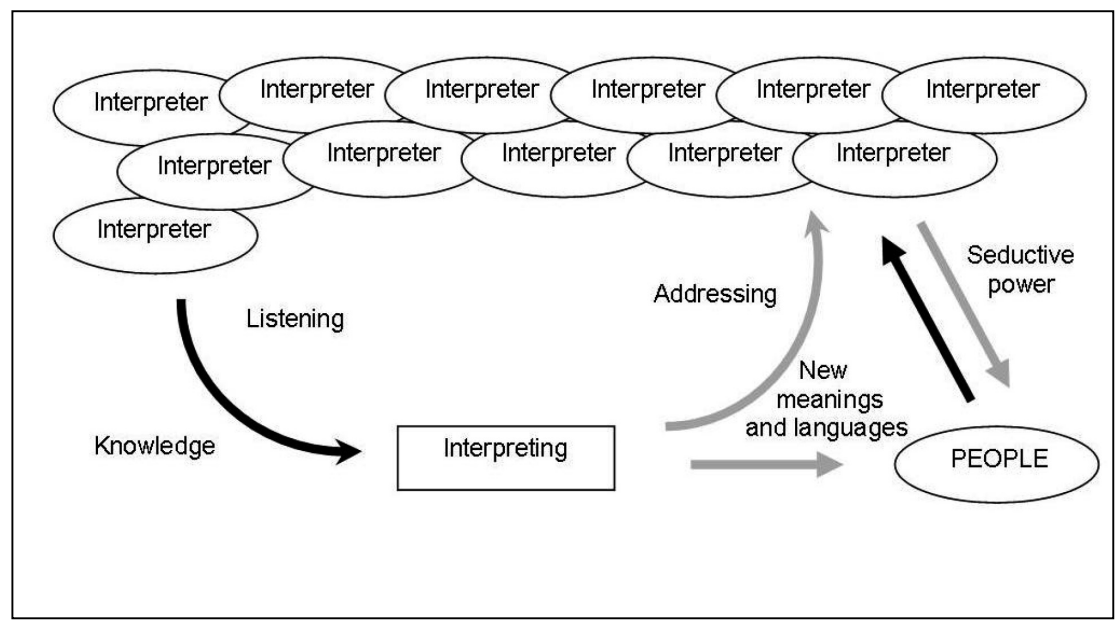

Source: [20]

In the first phase 'listening', there is listening to the key groups, i.e. interpreters. Interpreters are people who predict future development of customers'needs by means of their own research. The aim of 'listening' is to find the key groups of interpreters and predict benefits of their thoughts for business. The main key groups according to Verganti [20] are artists, cultural organizations, sociologists, anthropologists, marketers, retail and delivery firms, people, designers, firms in other industries, developers of pioneering projects, technology suppliers and research and educational institutions. The second phase is 'interpreting'. Its purpose within the company is to create such conditions that would propose a motion. The organization communicates with the interpreters and integrates their ideas with technology and possibilities of the company. The third phase is 'addressing'. This means making such conditions to be able to innovate, and to discuss the rationality and attractions of the change. 
Bruce \& Bessant [3] also state the major benefits of design management:

- Increase profit by increasing sales or by decreasing manufacturing costs.

- Increase market share.

- Gain a competitive advantage.

- Revamp mature and failing products.

- Provide a strategy for growth.

- Design is a way of launching a new product of service.

The UK Design Council focuses on the contribution made by design and presents mail responses [3]:

- $91 \%$ felt it improved the image of their company.

- $90 \%$ felt it improved quality of their products.

- $88 \%$ felt it helped them communicate more effectively with their customers.

- $84 \%$ felt it helped increase profit.

- $80 \%$ felt it helped into new markets.

- $70 \%$ felt it reduced costs.

Mazota [15] deals with topic Design as a competitive edge. Author measures impact of design on product, classifying the reasons for launching new products and the tacit knowledge of design. This research can be useful for professional design managers because it isolates variables that are pertinent to explain how design transforms management processes and which process it changes.

According to Bruce \& Cooper \& Vazquez [4] small companies have a range of business needs for design, but have varying levels of awareness and competency to manage design effectively. Two different types of companies could be discerned from the study: 'confident' and 'apprehensive' design users. The former companies had had experience with design, typically in previous work experience and the latter had little awareness of design. For the inexperienced design companies, various factors were identified that assisted the effective design outcome: the relative simplicity of the project, possession of strong briefing skills acquired in a different discipline, sourcing skills, such as personal recommendation form a trusted intermediary, and evaluation skills obtained through an intermediary or acquired in a different discipline.

\section{Problem Formulation}

The basic aim of research is to investigate the importance of design in Czech companies from the management of businesses' point of view. This paper also attempts to analyse and identify the awareness of companies of various sizes concerning the importance of design. The emphasis is put on the issues related to the correct targeting of such activities, which is closely related to the importance of design within companies. Finally, based on an analysis of the data collected, the study shows the current situation in Czech business.

\subsection{Research Methods}

The research consists of two main parts. In the first part of research done from January to March 2014, a method of smart internet questionnaires was used. It was designed by the authors of the paper based on the experience from their previous research.

The primary aim was to investigate companies' concern for design in relation to other factors. This was done by asking specific questions. The secondary aim was to investigate companies' concern for the importance of design itself.

In the second part of research, the results were analysed using quantification and by means of seeking a mutual dependence. The questionnaire form contains 16 questions. The responses were divided into several categories with common features. In total 168 entries collected from 305 addressed respondents took part in the research. The results obtained were subjects to a statistical study.

The results were subjects of critical assessment and a synthesis with already discovered and published data (secondary data) was carried out.

The table below shows the occupational structure of respondents who participated in the e-research.

The table above indicates that B2B and $\mathrm{B} 2 \mathrm{C}$ were almost equally represented $(53.5 \%$ and $46.5 \%)$ in the investigated area. The zero share in the respondent structure is represented by $B 2 G$ business. This means that the major share should just have $\mathrm{B} 2 \mathrm{C}$ and B2B sector. Firstly, a list of selected suitable subjects was done. Then, this list was sent to be filled in through the internet research questionnaires. 


\begin{tabular}{l|c|c} 
& relative (\%) & market orientation \\
\hline Subcontractor & 26.8 & \\
\hline Producer & 30.1 & B2B \\
\hline Service provider & 29.4 & $49.8 \%$ \\
\hline Merchant & 13.7 & \\
\hline
\end{tabular}

\begin{tabular}{l|c|c} 
& relative (\%) & market orientation \\
\hline Subcontractor & 9.7 & \\
\hline Producer & 33.8 & B2C \\
\hline Service provider & 35.3 & $50.2 \%$ \\
\hline Merchant & 21.1 & \\
\hline
\end{tabular}

Venn diagram visualisation was used for a better illustration (see Fig. 2). It is evident that some companies operate in both fields, whereas certain number of companies operates in one field only.

The Figure 3 shows the sectors structure of respondents, in which they operate.
The sample which has been used for the purpose of this paper contained $23 \%$ service respondents, $15 \%$ trade respondents, $10 \%$ building respondents, $13 \%$ engineering respondents, $4 \%$ food industry respondents, $1 \%$ textile industry respondent and $34 \%$ respondents that operate on the other sectors.

\section{Fig. 2: Venn diagram target group characteristics}

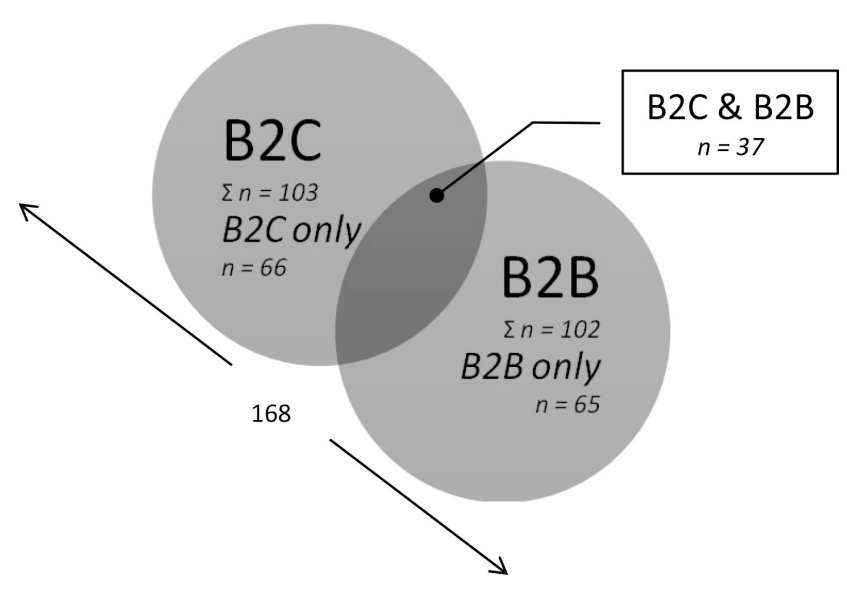

Source: own 


\begin{tabular}{l|c|c|c|c} 
Number of employees & B2B only & B2C only & $\begin{array}{c}\text { B2C and B2B } \\
\text { (both only) }\end{array}$ & Relative (\%) \\
\hline $\begin{array}{l}1-10 \\
\text { (Micro) }\end{array}$ & 9 & 18 & 1 & $16 \%$ \\
\hline $\begin{array}{l}11-50 \\
\text { (Small) }\end{array}$ & 10 & 11 & 8 & $17 \%$ \\
\hline $\begin{array}{l}51-200 \\
\text { (Medium-sized) }\end{array}$ & 15 & 15 & 6 & $22 \%$ \\
\hline $200+$ (Huge/big) & 31 & 22 & 22 & $45 \%$ \\
\hline
\end{tabular}

Source: own

\section{Fig. 3: Target group characteristics: Operating sectors}

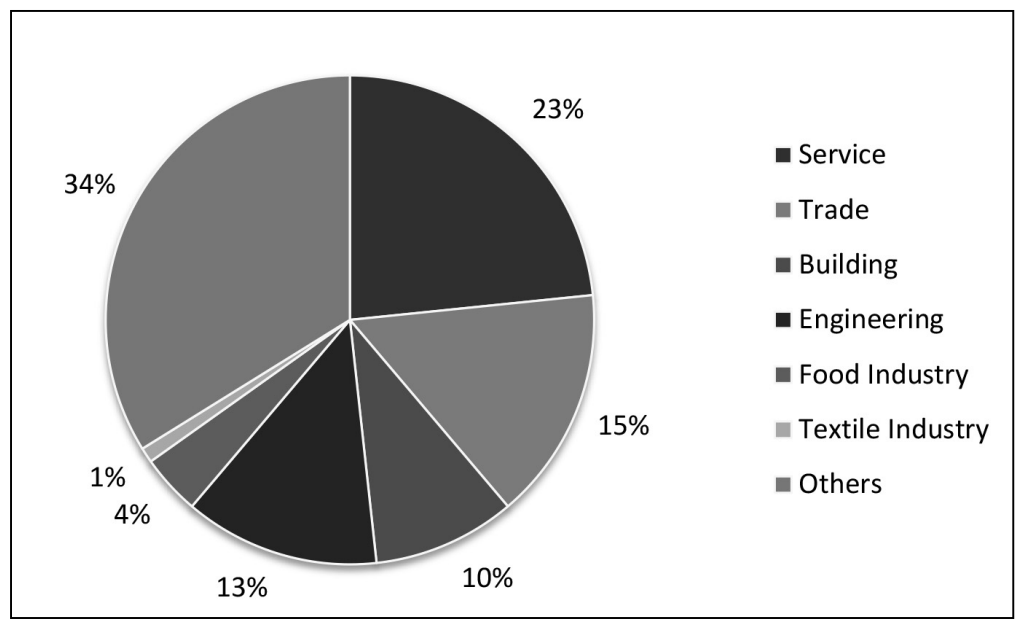

Source: own

\section{Problem Solutions}

The current state of the importance of design in a business concept of Czech companies in subjects examined on the Czech market is characterized by the following queries. In the case of a majority consensus, the data are quantified by a relative indicator and supplemented by important findings in the form of a comment. In the case of fragmentation of answers, only the most important findings in the surveyed area are listed.

Based on the problem solution above, two hypotheses were established. Hypotheses were tested on the level of significance of $\alpha=0.05$. The
H1 hypothesis was a subject to the Pearson's chi-squared $\chi^{2}$ test of independence [12] for a contingent table, using IBM SPSS Statistics software. P-value and Excel XLStatistics5 programme were used for statistical evaluation of the $\mathrm{H}_{2}$ hypothesis.

The value of the test-statistic is

$$
x^{2}=\sum_{i=1}^{r} \sum_{j=1}^{c} \frac{O_{i j}-E_{i j}}{E_{i j}}
$$

$\chi^{2}=$ Pearson's cumulative test statistic; 
$\mathrm{O}_{\mathrm{i}}=$ an observed frequency in a given contingency table;

$E_{i}=$ an expected (theoretical) frequency, asserted by the null hypothesis;

$r$ and $c$ are the number of rows and columns in the table, respectively. [9]

Then a standard deviation was calculated. This enabled us to see up to what extent typical cases vary within the set of examined numbers.

\subsection{Design with Respect to the Market Type}

Concerning the evaluation of design as one of the most important factors in the company, the following hypotheses were defined.
$\mathrm{H} 1_{0}$ : Referring to the importance of design in relation to the success rate of the company there is no difference between the companies having business in $\mathrm{B} 2 \mathrm{~B}$ and $\mathrm{B} 2 \mathrm{C}$ markets.

$\mathrm{H} 1_{\mathrm{A}}$ : Referring to the importance of design in relation to the success rate of the company there is difference between the companies having business in B2B and B2C markets.

The figure from above demonstrates the importance of design within the company according to its field of business. It is evident that across the spectrum 'fairly important' prevails. According to these numbers, companies in B2B market only are aware of a great importance of design. Slightly lower numbers are recorded

\section{Fig. 4: Graphical record of the evaluation regarding the importance of design from the perspective of companies and their business activities in the markets}

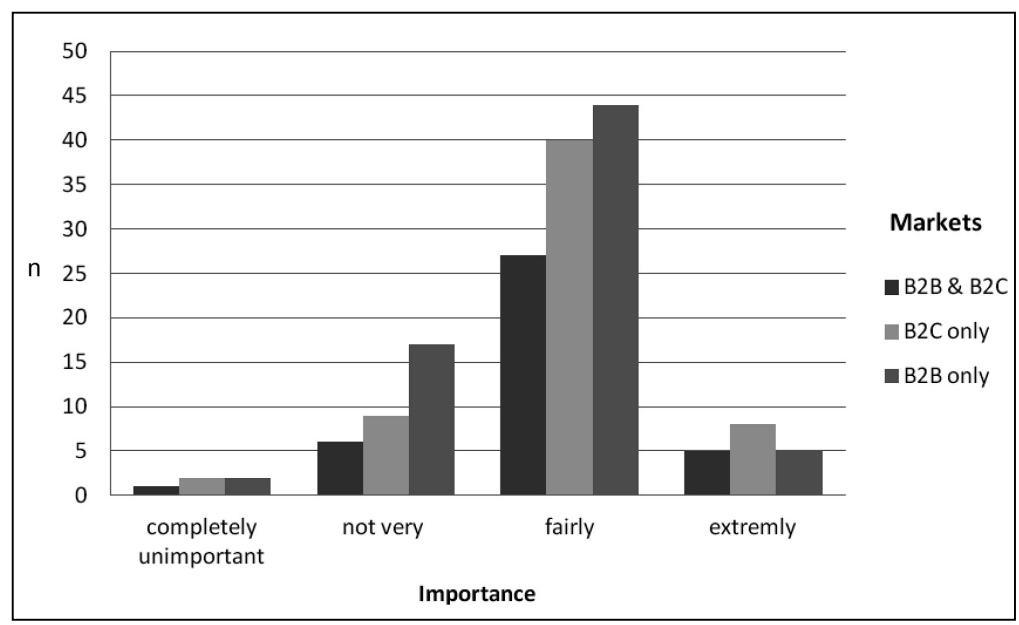

Source: own

within companies in $\mathrm{B} 2 \mathrm{C}$ market. Companies having business in $\mathrm{B} 2 \mathrm{~B}$ and at the same time in B2C markets took last place. Extreme numbers at both poles, i.e. 'extremely important' and 'completely unimportant', are very rare.

The next part focuses on the importance of design from companies' point of view. In the following Pearson's chi-square test for independence, the researchers strived to evaluate the importance of design from companies' point of view. The criterion of evaluation concerning the importance of this factor consisted of four levels: extremely important, fairly important, not very important, and completely unimportant.

Based on the hypothesis when p-value at 0.05 significance level was calculated with result of 0.756443221 , is this hypothesis $\mathrm{HO}$ rejected. It means that we cannot claim that there is no difference among the companies from $\mathrm{B} 2 \mathrm{~B}$ or $\mathrm{B} 2 \mathrm{C}$ markets with respect to the importance of design. 


\section{(Pearson) Chi-square Test}

(For independence of importance of design and typ of market

$\mathrm{H}_{0}$ : Variables are independent (no interaction between variables)

$\mathrm{H}_{1}$ : Variables are dependent (interaction between variables)

Chi-square 3.405907985

DF 6

$\mathrm{p}$-value $=0.756443221$

From the visual representation of respective factors concerning the importance of companies' activities in the markets, a simple spider graph analysis was drawn up. The spider analysis includes criteria according to which the companies consider the importance. These are quality, reliability, design and price. Low numbers show insignificant importance (1 - completely unimportant), whereas high numbers represent great importance (4-extremely important). This reflects degrees of importance concerning the evaluation of internal factors based on a well thought-out indicator system. The factor rating enables us to answer the following questions: 'What are the most important factors within companies?' and
'What is the situation like regarding the selected factor within a company?' A structure of the factor-rating model is to be found in Figure 5 below.

For a more precise representation of the measured results, the axis numbers in the spider graph were adjusted at number intervals 2.0 to 4.0. This spider chart represents that in the market B2C only, quality is the most important factor with the value of 3.56 , then there is reliability with the value of 3.46 , price with the value of 3.20 , and design with the lowest value of 2.92 .

In the market $\mathrm{B} 2 \mathrm{~B}$ only, quality with the value of 3.69 is the most important factor together with reliability with a very similar value of 3.68 . The

\section{Fig. 5: Spider chart regarding the importance of respective criteria}

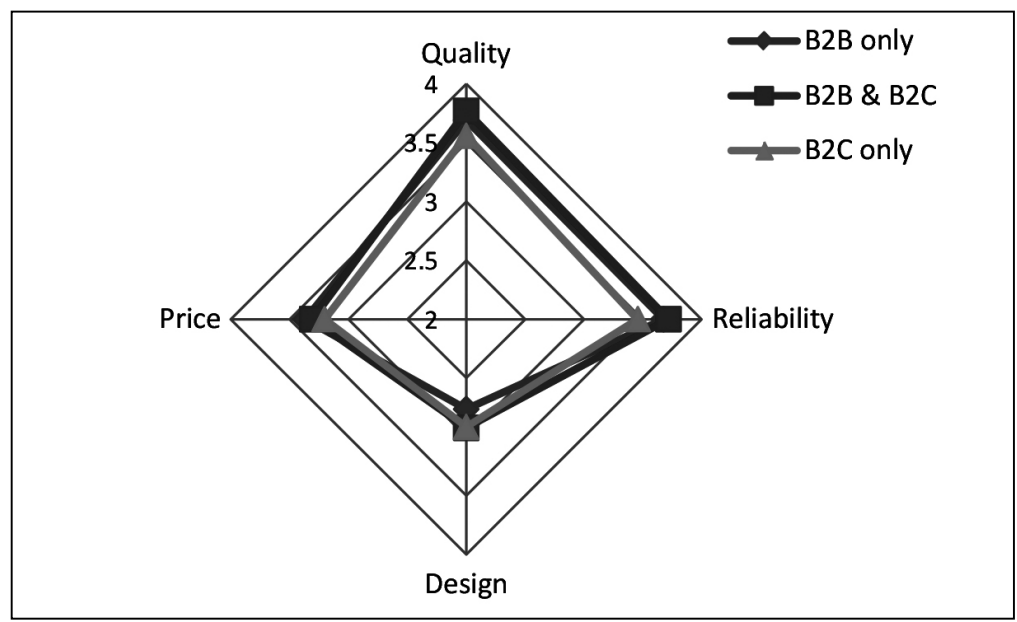




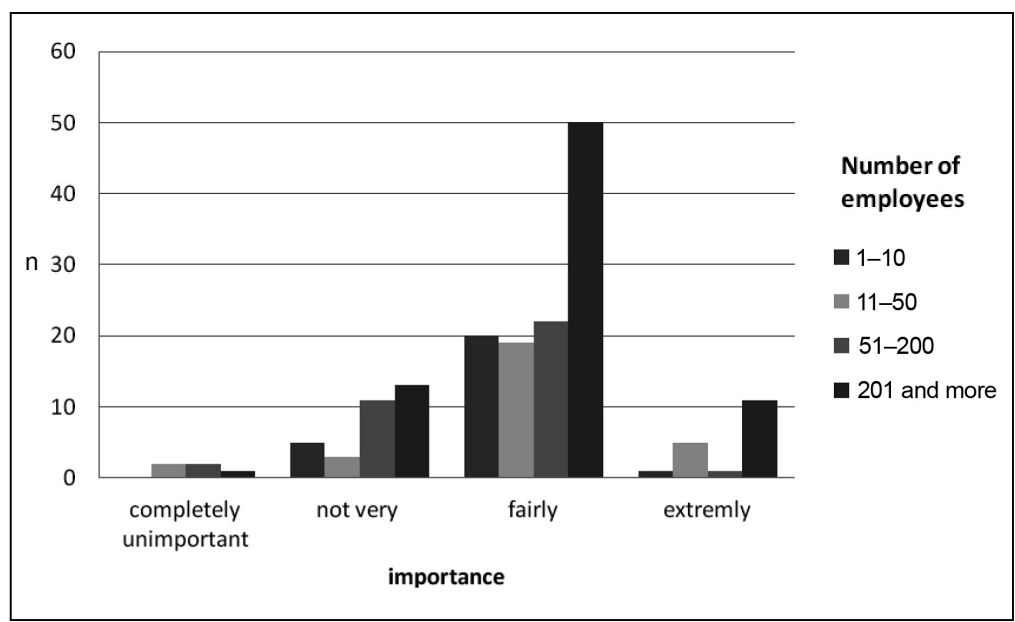

Source: own

factor of price reached a lower value of 3.37 and design is again of lowest importance with the value of 2.76. In the companies that have their business activities in B2B and B2C markets, the situation is almost identical. Quality is again the most important factor with the value of 3.77 , then reliability with the value of 3.72 . Price is at the value of 3.31 and design is again of the lowest importance with the value of 2.92 .

\subsection{Design with Respect to the Company Size}

For the purpose of research concentrating on the importance of design compared with the company size, the following hypotheses were defined.

$\mathrm{H}_{2}$ : Referring to the importance of design in relation to the success rate of the company there is no difference among small, mediumsized and large businesses.

$\mathrm{H}_{2}$ : Referring to the importance of design in relation to the success rate of the company there is difference among small, medium-sized and large businesses.

Considering the evaluation of design itself as one of the factors that were stated by the companies in the graph above, we are able to note the following. Small businesses with 1-10 employees and medium-sized businesses with 11-50 employees as well as large businesses with 51-200 employees are of a very similar opinion. According to their opinion, the statement that design is relatively important occurs most often. A small number of businesses consider design extremely important, not very important or completely unimportant. A very similar situation is in large businesses with 201 employees and more when 50 businesses consider design fairly important. The entry 'extremely important' is insignificant and 'not very important' is of almost identical low value as 'extremely important'.

Based on the hypothesis when p-value at 0.05 significance level was calculated with result of 0.143148809 , is this hypothesis $\mathrm{HO}$ rejected. It means that we cannot claim that there is no difference among the companies regarding the dependence on number of employees and the attitude towards the importance of design. Spider graph analysis regarding visual record of the evaluation of respective criteria from the perspective of companies' size was made. 


\section{Tab. 5: Screenshot for H2 Chi-square}

\section{Analysis of $r \times c$ tables}

(Pearson) Chi-square Test

(For independence of importance of design and number of employees)

$\mathrm{H}_{0}$ :Variables are independent (no interaction between variables)

$\mathrm{H}_{1}$ : Variables are dependent (interaction between variables)

\begin{tabular}{r|l}
\hline Chi-square & 13.45319424 \\
\hline DF & 9 \\
\hline p-value $=$ & 0.143148809 \\
\hline
\end{tabular}

Source: own

\section{Fig. 7: Spider chart regarding the importance of respected criteria from the perspective of companies' size}

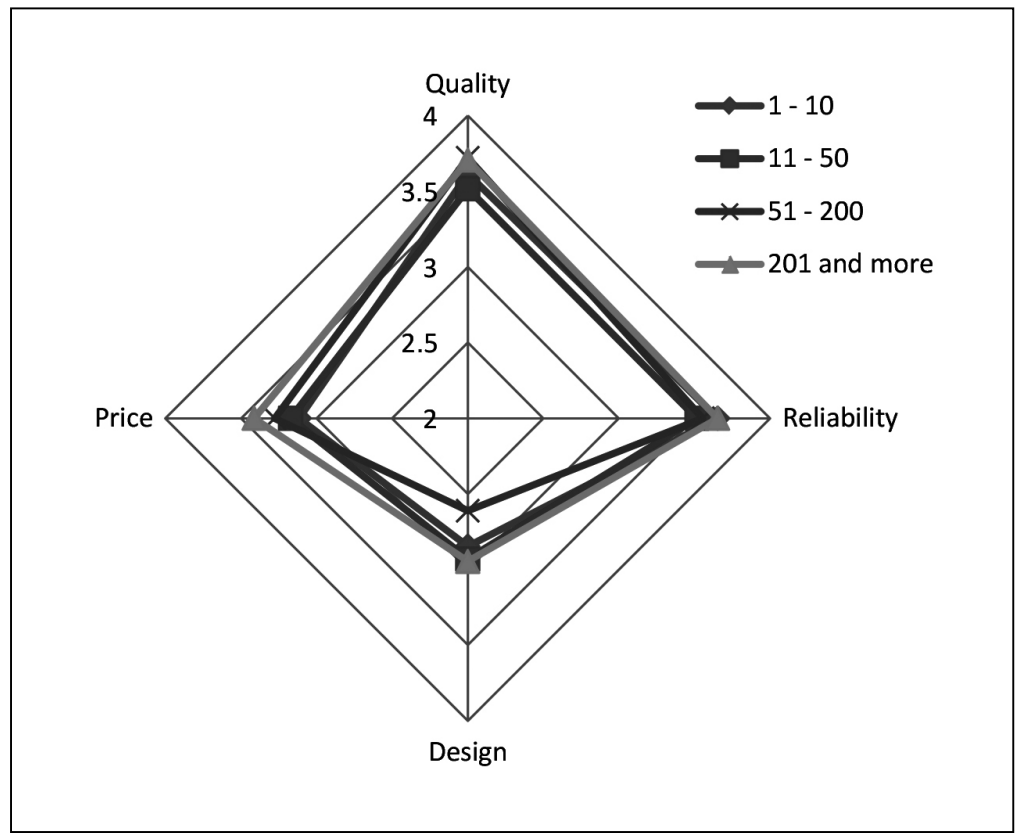

Source: own

The spider analysis was done by means of quantified responses. The number 4.0 represents the highest importance, whereas the number 1.0 represents the lowest importance. For a more precise representation of the measured results, the axis numbers in the spider graph were adjusted at number intervals 2.0 to 4.0 . It is evident that regarding small businesses with 1-10 employees, reliability with the value of 3.65 is of the highest importance. Then, quality with the value of 3.62 follows. Price with the value of 3.12 comes third. 
Design with the lowest value of just 2.85 takes last place concerning the importance. Mediumsized businesses with 11-50 employees see the importance of respective factors as follows: quality and reliability with the same value of 3.52 , price with the value of 3.17 , design again with the lowest value of 2.93. Mediumsized businesses with 51-200 employees reached very similar values as medium-sized businesses with 11-50 employees. The most important factor is quality with the value of 3.72 , reliability with the value of 3.56 follows. Then, there is price with the value of 3.28 . Design takes last place with the value of 2.61. Large businesses with 201 employees and more evaluate the selected factors in the same order as medium-sized businesses: quality (3.71), reliability (3.65), price (3.41), and design (2.95).

\subsection{The Importance of Design Regarding Characteristic of Data's Position and Variability}

From the data collected through electronic forms, the following statistical indexes were calculated: characteristics of data's position (arithmetic mean and median value) and characteristics of data's variability (variance and standard deviation).

Arithmetic mean of 2.86 represents a typical value describing a file of various values. We state that there is not a great difference regarding values recorded within respective fields of business (Fig. 5) or company size (Fig. 6). The data examined reaches a low variance of 0.4 , which represents favourable data consistency. Standard deviation of 168 entries regarding the

\section{Tab. 6: Calculation of selected statistical indexes of data file under review}

\begin{tabular}{l|c} 
Number of values $(n)$ & 168 \\
\hline Arithmetic mean & 2.86 \\
\hline Median value & 3 \\
\hline Variance $\left(s^{2}\right)$ & 0.4 \\
\hline Standard deviation $(s)$ & 0.63 \\
\hline
\end{tabular}

Source: own

importance of design within companies shows how typical cases within the data collected vary. The value of 0.63 means that in most cases the elements within data collected are alike, therefore only a low disparity occurs.

From the analysed results, we understand that companies with respect to their size and business activities in particular markets see the importance of the following factors: quality, reliability, design and price. In general, design is least important. Regarding almost all the fields, quality comes first, and then, reliability together with price is of the same importance in the second and third place.

\section{Conclusion}

Nowadays, businesses are definitely aware of design being an important part of business prosperity. One of the major criteria is to become different in the market and for that reason design is fundamental in this discipline. Many businesses have already started working on it; others are in the phase of being aware of it but not concentrating on this area. These have not started solving the situation in any way. They probably feel that design is their weakness that they want to work on and improve in the future.

At present, companies are becoming more aware of the importance of design regarding their products as well as their marketing materials. Unfortunately, in comparison with international research activities it must be declared that majority of companies in the Czech Republic still underestimate the role of design. Even though companies pay attention to design, they do not consider it strategically important for business prosperity. By doing the research in the Czech Republic using a sample of 168 companies it was found out that there is a difference regarding perception of the importance of design in B2B and B2C markets. This corresponds with an increasing importance of design for final consumers. Design represents a very important competitive 
factor that influences their final decision. On the contrary, the company size specification from number of employees' perspective does not influence perception of the importance of design in Czech companies.

Companies put emphasis on the quality of products in the first place. In fact, a long-term and transactional marketing considers the quality as one of essential pillars of successful marketing strategy. Reliability comes second, not design. The explanation is clear. Companies' great concern is to offer a high-quality product, to be reliable (accuracy, amount and perfection of supplies, invoice payment, and trust in business partner). Then, there is the price of product. Czech market is traditionally very sensitive to the price and companies are definitely aware of this fact. For this reason, design is naturally moving to the last place with respect to these four basic criteria. Novotný and Duspiva [17] present very similar results in their research. They define the factors influencing consumers' buying behaviour and their importance for enterprises. Based on their results of the research a model of identical and nonidentical factors influencing purchase consumers' behaviour and the model cobwebs were drawn. Novotný and Duspiva [17] define following 15 factors:

1. Quality.

2. Price.

3. Design.

4. Service.

5. Experience.

6. Colour.

7. Discount.

8. Convenience.

9. Reference.

10. Brand.

11. Origin.

12. Public relations.

13. Trends.

14. Advertising.

15. Package.

As we can see, the research confirms results of our research.

It is evident that nowadays, in the period of economic stagnation, companies must primarily maintain their position in the market which is typical for poor demand. They cannot afford to invest money and energy in the development of high-quality design. According to estimates of Czech Ministry of Finance and The European Central Bank, we expect the growth in gross domestic product of Czech economy in 2015 by
1.7-2.0 percent [11]. With respect to economic growth and positive market news, companies could make their economic situation more stable and start dealing with design more strategically.

\section{References}

[1] ABECASSIS-MOEDAS, C. and MAHMOUDJOUINI, S.B. Absorptive capacity and sourcerecipient knowledge complementarity in designing new products: an empirically derived framework. Journal of Product Innovation Management. 2008, Vol. 25, Iss. 5, pp. 47390. ISSN 1540-5885. DOI: 10.1111/j.15405885.2008.00315.x.

[2] ADIR, G., ADIR, V. and PASCU, N.E. Logo design and the corporate identity. ProcediaSocial and Behavioral Sciences. 2012, Vol. 51, pp. 650-654. ISSN 1877-0428. DOI: 10.1016/j. sbspro.2012.08.218.

[3] BRUCE, M. and BESSANT, J. Design in Business. Strategic Innovation Through Design. Harlow: Pearson Education Limited, 2002. ISBN 978-0-273-64374-6.

[4] BRUCE, M., COOPER, R. and VAZQUEZ, D. Effective design management for small businesses. Design studies. 1999, Vol. 20, Iss. 3 , pp. 297-315. ISSN 0142-694X. DOI: 10.1016/ S0142-694X(98)00022-2.

[5] BEST, K. Design Management: Managing Design Strategy, Process and Implementation. Lausanne: AVA Publishing SA, 2006. ISBN 9782-940373-12.3.

[6] DESIGN MANAGEMENT INSTITUTE. What is Design Management? [online]. Boston, MA: Design Management Institute, 2014 [cit. 2014-06-05]. Available from: http://www.dmi. org/?What_is_Design_Manag.

[7] GORB, P. Corporate identity design; Its contribution to effective management. European Management Journal. 1988, Vol. 6, Iss. 3, pp. 205-208. ISSN 0263-2373.

[8] HERTENSTEIN, J.H., BLATT, M.B. and VERYZER, R.W. The impact of industrial design effectiveness on corporate financial performance. Journal of Product Innovation management. 2005, Vol. 22, Iss. 1, pp. 3-21. ISSN 1540-5885. DOI: 10.1111/j.07376782.2005.00100.x.

[9] HINDLS, R. Metody statistické analýzy pro ekonomy. 8. vyd. Praha: Professional Publishing, 2007. ISBN 978-80-86946-43-6.

[10] HOLLINS, B. Design management education: The UK experience. Design Management Journal. 2002, Vol. 13, Iss. 3, pp. 
25-29. ISSN 1948-7169. DOI: 10.1111/j.19487169.2002.tb00315.x.

[11] MINISTRY OF FINANCE OF THE CZECH REPUBLIC. Survey of macroeconomic forecasts - April 2014 [online]. Prague: Ministry of Finance of the Czech Republic, 2014 [cit. 2014-06-05]. Available from: http://www.mfcr.cz/en/statistics/ macroeconomic-forecast/2014/survey-ofmacroeconomic-forecasts-april-17638.

[12] MCDONALD, J.H. Handbook of Biological Statistics. Baltimore, Maryland: Sparky House Publishing, 2008. 287 p.

[13] MELEWAR, T.C., DENNIS, C. and KENT, A. Global design, marketing and branding: introduction to the special issue. Journal of Business Research. 2014, Vol. 67, Iss. 11, pp. 2241-2242. ISSN 0148-2963. DOI: http://dx.doi. org/10.1016/j.jbusres.2014.06.011.

[14] MOZOTA, B.B. Design and competitive edge: $A$ model for design management excellence in European SMEs1. Academic Review. 2002, Vol. 2, Iss. 1, pp. 88-103. ISSN 1948-71. DOI: 10.1111/j.1948-7177.2002. tb00014.x.

[15] MOZOTA, B.B. Design management: using design to build brand value and corporate innovation. New York: Allworth Press, 2003. ISBN 978-1581152838.

[16] MOZOTA, B.B. The four powers of design: $A$ value model in design management. Design Management Review. 2006, Vol. 17, Iss. 2, pp. 44-53. ISSN 1948-7169. DOI: 10.1111/j.19487169.2006.tb00038.x.

[17] NOVOTNÝ, J., DUSPIVA, P. Faktory ovlivňující kupní chování spotřebitelů a jejich význam pro podniky. E+M Ekonomie a Management. 2012, Vol. 17, Iss. 1, pp. 152166. ISSN 1212-3609.
[18] STAMM, B. Managing innovation, design and creativity. Chichester: John Wiley \& Sons, 2008. ISBN 978-0-470-51066-7.

[19] URABE, K., CHILD, J. and KAGONO, T. Innovation and management. International Comparisons. Berlin, New York: de Gruyter, 1988. ISBN 3-11-013947-2.

[20] VERGANTI, R. Design Driven Innovation. Boston: Harvard Business School Publishing Corporation, 2013. ISBN 978-1-4221-2482-6.

[21] VYSEKALOVÁ, J., MIKEŠ, J. Image a firemní identita. Praha: Grada, 2009. ISBN 978-80-247-2790-5.

[22] WALKER, D. Design Management: A Handbook of Issues and Methods. Oxford: Blackwell, 1990. ISBN 978-0631154044.

Mgr. Jan Kramoliš, Ph.D.

Tomas Bata University in Zlín Faculty of Management and Economics Department of Economics kramolis@fame.utb.cz

doc. Ing. Pavla Staňková, Ph.D.

Tomas Bata University in Zlín

Faculty of Management and Economics Department of Management and Marketing stankova@fame.utb.cz

Mgr. Michal Richtr

Tomas Bata University in Zlín

Faculty of Management and Economics Department of Management and Marketing michal@dynamodesign.cz 


\title{
Abstract
}

\section{THE IMPORTANCE OF DESIGN IN BUSINESS PRACTICES OF CZECH COMPANIES}

\author{
Jan Kramoliš, Pavla Staňková, Michal Richtr
}

In the context of discussions about the role of innovation in business policy and marketing activities, questions of design to participate in the innovation success are often considered. The main aim of this paper is to comprehensively review the sources of design management. Furthermore, the study shows current situation in Czech business. This paper also attempts to analyse and identify the awareness of companies of various sizes concerning the importance of design. The primary aim of research was to investigate companies' concern for design in relation to other factors: price, quality and reliability.

A comprehensive review of the extant literature and journals identified several sources of design approach for Czech companies. The research consists of two main parts. Firstly, a method of smart internet Google SpreadSheets questionnaires designed by the authors was used. Total of 168 entries collected from 305 addressed respondents were used in the research. In the second part of research, the results were analysed using quantification and by means of seeking a mutual dependence. The results obtained were subjects to a statistical study. The results of the research have offered interesting findings. It was discovered that design represents a very important competitive factor that influences firms' final decision. On the other hand, quality, reliability and price are still perceived as more interesting factors of innovation. Briefly, design is not likely to be perceived as the main innovation factor in the Czech Republic.

This paper identifies several interesting aspects regarding design within Czech companies, including the mindset of management.

Key Words: Innovation, design, management, quality, price, reliability.

JEL Classification: M21, 031.

DOI: 10.15240/tul/001/2015-2-011 